\title{
INFLUENCE OF THE ETHNIC AFFILIATION, LEVEL OF EDUCATION AND PLACE OF LIVING ON ORAL HEALTH AT GERIATRIC POPULATION WITH TOTAL AND PARTIAL DENTURES IN REPUBLIC OF MACEDONIA
}

\author{
Natasha Stavreva, Ljuben Guguvcevchi, Biljana Kapusevska
}

Department of Prosthetics, Faculty of Dentistry Skopje, Ss.Cyril and Methodius University

Skopje, R. Macedonia

Corresponding Author: Stavreva Natasha, Clinic of Prosthodontics, Faculty of Dentistry. 1000 Skopje, R. Macedonia, Mob: + 38970 308939, E-mail: natasha_stavreva@yahoo.com

\begin{abstract}
Introduction. Health is the main component of the quality of life, while oral health is component of the general health. The socio-demographic characteristics are one of the important factors for perception of the oral health and the quality of life. The main purpose of this study was to perform an evaluation of the quality of life of geriatric patients (older than 65) with built-in oral prosthetic dentures depending on the ethnic affiliation, level of education and place of living, as sociodemographic characteristics.

Materials and methods. The survey was a prospective transversal (cross-sectional) study conducted among 165 institutionally sheltered patients at the Gerontology Institute (inspected group - IG) and 170 patients from the dental specialist clinics (control group CG) at the age of 65 and older. The statistical program SPSS for Windows ver. 13.0 was used for statistical processing.

Results and discussion. Patients with upper and lower total dentures dominated (43.6\% vs. 26.5\%). The highest GOHAI score had the other ethnicities of IC (32.08) and Roma of IG (31.00), while the lowest was in the Albanians of CG (25.91). The highest value of 30.15 had the IG of patients living in urban areas.

Conclusion. The quality of life and oral health of the geriatric patients are at unsatisfactory level, with significant influence of the place of living and insignificant influence of the ethnic affiliation and level of education.
\end{abstract}

Key words: GOHAI indicator, quality of life, ethnic, education, place of living

\section{Introduction}

Health and health conditions are the basic components of quality of life at overall population.

In general, oral health affects different countries, cultures, sex structures, age groups, particularly the older population, including the geriatric one, which is a specific category, where the number has been continually growing since the end of the last century. [1]

One of the most frequently used and accepted definitions of the quality of life, suppor- ted with the theory and practice of promotion of health, is of the Center for Health Promotion at the Toronto University: "Quality of life is in connection with the degree of which the person enjoys in important possibilities of its life". This definition may be used as "How good is your life to you". [2, 3, 4, 5]

Since the quality of life is directly connected with oral parameters, whose aim is to give information for the condition of oral cavity and its influence to the general health and quality of life, Coen and Jago in 1976 defined 
socio-dental indicators (questionnaires) used to assess nonclinical influence of oral disorders to the social, physical and psycho-physical aspects of life, controlled by the personal and subjective understanding for the health and disease. $[6,7,8]$

One of the important factors for the perception of oral health and quality of life are the social-demographic characteristics.

The main purpose of this study was to evaluate the quality of life of the geriatric patients (aged > 65) in connection to the type of the built-in oral prosthetic dentures, ethnic affiliation, level of education and place of living, and social-demographic characteristics.

\section{Materials and methods}

The study was observational, transversal cross-section study, performed on a population of over 65 years in a group of 165 patients from the Gerontology Institute "13November" - Skopje and a group of 170 patients from the dental specialist hospitals in the city of Skopje.

The patients were categorized into six prosthetics categories (subgroups):

- Group 1 -Upper and lower total denture

- Group 2 -Upper and lower partial denture

- Group 3 - Upper partial and lower total denture

- Group 4 -Upper total and lower partial denture

- Group 5 - Upper or lower partial denture only

- Group 6 - Upper or lower total denture only
The WHO Oral health paper and the GOHAI indicator were used as instruments. The WHO Oral health paper was used to get the relevant data for socio-demographic characteristics (sex, age, ethnic affiliation, place of living) with two added questions for the level of education and the social-economic status. (Annex 1)

The main instrument was a standardized GOHAI indicator, with 12 questions, with answers ranged according to the Lickert scale $(0=$ never, $1=$ not often, $2=$ sometimes, $3=$ often, $4=$ very often) (Annex 2). The results can range between $0-48$, where the higher score indicates the the lower oral health and quality of life.

SPPS for Windows ver. 13.0 was used as statistical software for data processing. During the computer analysis adequate statistical methodologies were used. The values for $p<0.05$ were statistically significant, while the values for $\mathrm{p}<0.01$ were statistically highly significant.

\section{Results}

The analysis of the results in both groups shows that institutionally sheltered patients had significantly more often upper and lower total dentures compared to the upper partial and lower total denture, upper or lower partial denture only and upper or lower total denture only. (Table 1, Graph 1)

Table 1

Type of edentulous-IG/CG

\begin{tabular}{|c|c|c|c|c|c|}
\hline \multirow[b]{2}{*}{ Type of edentulous } & \multicolumn{4}{|c|}{ Group } & \multirow[b]{2}{*}{ Total } \\
\hline & \multicolumn{2}{|c|}{$\begin{array}{c}\text { IG } \\
\text { (Number of patients } \\
\text { / percentage) }\end{array}$} & \multicolumn{2}{|c|}{$\begin{array}{c}\text { CG } \\
\text { (Number of patients / } \\
\text { percentage) }\end{array}$} & \\
\hline Upper and lower total denture & 72 & $43.64 \%$ & 45 & $26.47 \%$ & 117 \\
\hline Upper and lower partial denture & 33 & $20.00 \%$ & 35 & $20.59 \%$ & 68 \\
\hline Upper partial and lower total denture & 15 & $9.09 \%$ & 31 & $18.24 \%$ & 46 \\
\hline Upper total and lower partial denture & 24 & $14.55 \%$ & 19 & $11.18 \%$ & 43 \\
\hline Upper or lower partial denture only & 12 & $7.27 \%$ & 19 & $11.18 \%$ & 31 \\
\hline Upper or lower total denture only & 9 & $5.45 \%$ & 21 & $12.35 \%$ & 30 \\
\hline Total & 165 & $100.00 \%$ & 170 & $100.00 \%$ & 335 \\
\hline
\end{tabular}

Pearson Chi-square $\quad=18.75 \mathrm{df}=5 \mathrm{p}=0.002$

$1 / 3$ Pearson Chi-square $=11.1 \quad \mathrm{df}=1 \mathrm{p}=0.00086$

$1 / 5$ Pearson Chi-square $=5.2 \quad \mathrm{df}=1 \mathrm{p}=0.022$

$1 / 6$ Pearson Chi-square $=9.6 \quad \mathrm{df}=1 \quad \mathrm{p}=0.002$

3/4 Pearson Chi-square $=4.86 \mathrm{df}=1 \mathrm{p}=0.027$

4/6 Pearson Chi-square $=4.75 \mathrm{df}=1 \mathrm{p}=0.029$ 


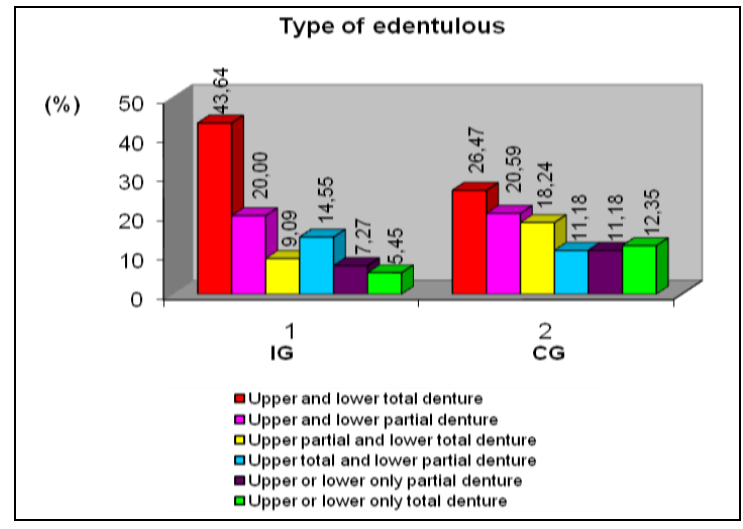

Graph 1 - Type of edentulous - IG/CG
Statistically, highly significant difference in the total GOHAI score was recorded only among the patients from IG and CG ( $\mathrm{p}=$ 0.000085), while the ethnic affiliation had no significant influence to the score. (Table 2)

The highest value of the GOHAI score had the patients of the IG of other nationalities and Roma from the IG, while the lowest value of the score was recorded in the Albanians in the CG. (Table 3, Graph 2)

Table 2

ANOVA-MANOVA (total GOHAI score/ethnic affiliation)

\begin{tabular}{|l|c|c|c|c|c|}
\hline \multicolumn{7}{|l|}{ Univariate Tests of Significance for GOHAI total score } \\
\hline & SS & $\begin{array}{c}\text { Degr. } \\
\text { of }\end{array}$ & MS & F & p \\
\hline Intercept & 129216.3 & 1 & 129216.3 & 7960.44 & 0.00 \\
\hline Ethnic group & 114.9 & 4 & 28.7 & 1.77 & 0.13 \\
\hline IG/CG & 257.1 & 1 & 257.1 & 15.84 & 0.000085 \\
\hline Ethnic group * IG/CG & 148.2 & 4 & 37.1 & 2.28 & 0.06 \\
\hline Error & 5275.5 & 325 & 16.2 & & \\
\hline
\end{tabular}

Table 3

ANOVA-MANOVA (total GOHAI scorelethnic affiliation)

\begin{tabular}{|l|c|c|c|c|c|c|}
\hline \multirow{2}{*}{ Ethnic group } & \multirow{2}{*}{ IG/CG } & \multicolumn{5}{|c|}{ Total GOHAI score } \\
\cline { 3 - 7 } & & $\begin{array}{c}\text { GOHAI } \\
\text { mean }\end{array}$ & $\begin{array}{c}\text { GOHAI } \\
\text { Std. Error }\end{array}$ & $\begin{array}{c}\text { GOHAI } \\
\mathbf{- 9 5 . 0 0 \%}\end{array}$ & $\begin{array}{c}\text { GOHAI } \\
\mathbf{+ 9 5 . 0 0 \%}\end{array}$ & $\mathbf{N}$ \\
\hline \multirow{2}{*}{ Macedonians } & IG & 29.32 & 0.39 & 28.56 & 30.08 & 109 \\
\cline { 2 - 7 } & CG & 28.71 & 0.39 & 27.94 & 29.48 & 107 \\
\hline \multirow{2}{*}{ Albanians } & IG & 29.79 & 0.82 & 28.17 & 31.41 & 24 \\
\cline { 2 - 7 } & CG & 25.91 & 0.86 & 24.22 & 27.60 & 22 \\
\hline \multirow{2}{*}{ Turks } & IG & 30.93 & 1.08 & 28.81 & 33.05 & 14 \\
\cline { 2 - 7 } & CG & 28.28 & 0.95 & 26.41 & 30.15 & 18 \\
\hline \multirow{2}{*}{ Roma } & IG & 31.00 & 1.64 & 27.76 & 34.24 & 6 \\
\cline { 2 - 7 } & CG & 28.93 & 1.08 & 26.81 & 31.05 & 14 \\
\hline \multirow{2}{*}{ Other } & IG & 32.08 & 1.16 & 29.80 & 34.37 & 12 \\
\cline { 2 - 7 } & CG & 28.22 & 1.34 & 25.58 & 30.86 & 9 \\
\hline
\end{tabular}

The results of the ANOVA-MANOVA analysis are shown in Table 4 for the assessment of the influence of the level of education to the quality of life, analyzed by the total GOHAI score.

The main results showed statistically significant difference in the total GOHAI score only among the patients from the IG and the
$\mathrm{CG}(\mathrm{p}=0.03)$, while the level of education had no significant influence to the GOHAI score. (Table 4)

The patients from the IG with primary, secondary and high school education had the highest GOHAI scores compared to the patients from CG. (Table 5, Graph 3) 


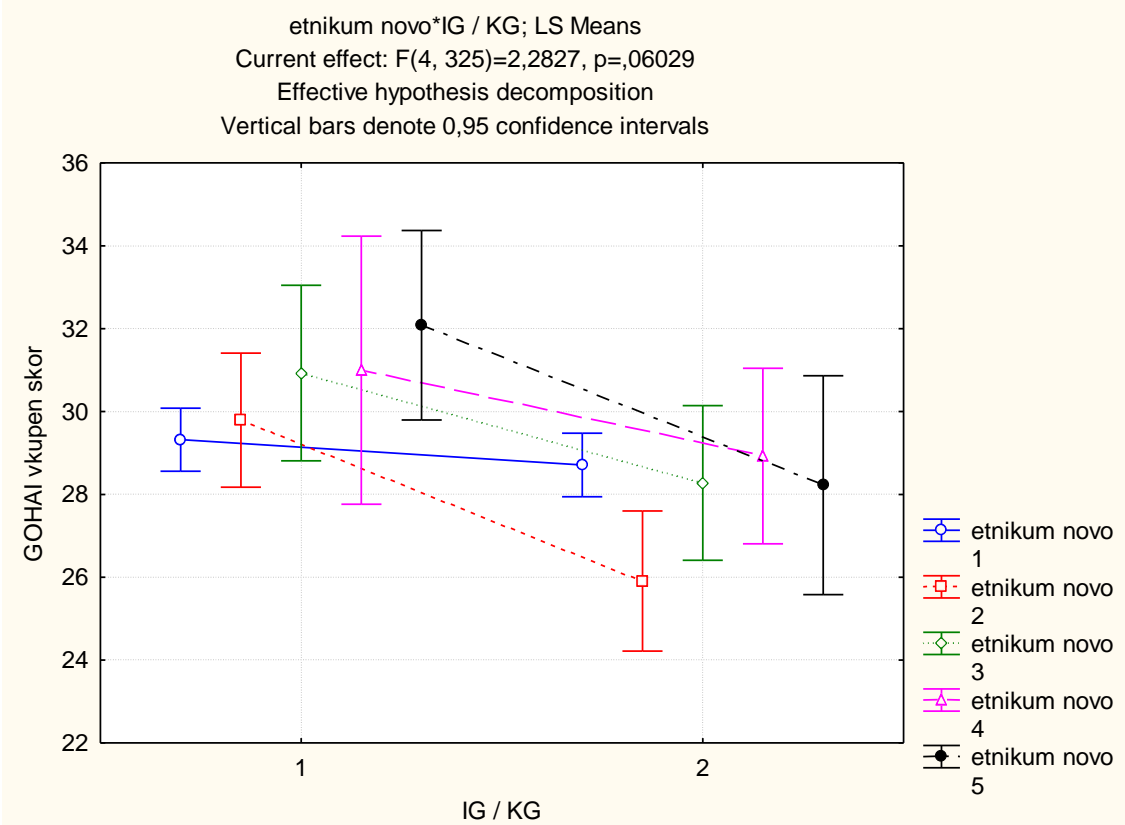

Graph 2 - ANOVA-MANOVA (total GOHAI score/ethnic affiliation)

Table 4

ANOVA-MANOVA (total GOHAI score/level of education)

\begin{tabular}{|l|r|r|r|r|r|}
\hline \multicolumn{6}{|c|}{ Univariate Tests of Significance for GOHAI total score } \\
\hline & \multicolumn{1}{|c|}{ SS } & $\begin{array}{c}\text { Degr. } \\
\text { of }\end{array}$ & \multicolumn{1}{c|}{ MS } & \multicolumn{1}{c|}{ F } & p \\
\hline Intercept & 201924.6 & 1 & 201924.6 & 12204.12 & 0.00 \\
\hline Education & 33.8 & 3 & 11.3 & 0.68 & 0.56 \\
\hline IG/CG & 75.4 & 1 & 75.4 & 4.55 & 0.03 \\
\hline $\begin{array}{l}\text { Education * } \\
\text { IG/CG }\end{array}$ & 101.9 & 3 & 34.0 & 2.05 & 0.11 \\
\hline Error & 5410.4 & 327 & 16.5 & & \\
\hline
\end{tabular}

Table 5

ANOVA-MANOVA (total GOHAI score/level of education)

\begin{tabular}{|l|c|c|c|c|c|c|}
\hline \multirow{3}{*}{ Education } & \multirow{2}{*}{ IG.CG } & \multicolumn{5}{|c|}{ Total GOHAI score } \\
\cline { 3 - 7 } & & $\begin{array}{c}\text { GOHAI } \\
\text { mean }\end{array}$ & $\begin{array}{c}\text { GOHAI } \\
\text { Std. Error }\end{array}$ & $\begin{array}{c}\text { GOHAI } \\
\mathbf{- 9 5 , 0 0 \%}\end{array}$ & $\begin{array}{c}\text { GOHAI } \\
\mathbf{+ 9 5 , 0 0 \%}\end{array}$ & N \\
\hline \multirow{2}{*}{ Primary } & IG & 30,02 & 0,45 & 29,15 & 30,90 & 83 \\
\cline { 2 - 7 } & CG & 27,97 & 0,48 & 27,04 & 28,90 & 73 \\
\hline \multirow{2}{*}{ Secondary } & IG & 30,04 & 0,59 & 28,89 & 31,20 & 48 \\
\cline { 2 - 8 } & CG & 28,80 & 0,60 & 27,62 & 29,00 & 46 \\
\hline \multirow{2}{*}{ High } & IG & 30,13 & 1,02 & 28,12 & 32,12 & 16 \\
\hline \multirow{2}{*}{ University } & CG & 27,67 & 0,78 & 26,13 & 29,21 & 27 \\
\cline { 2 - 8 } & IG & 27,72 & 0,96 & 25,84 & 29,61 & 18 \\
\hline
\end{tabular}




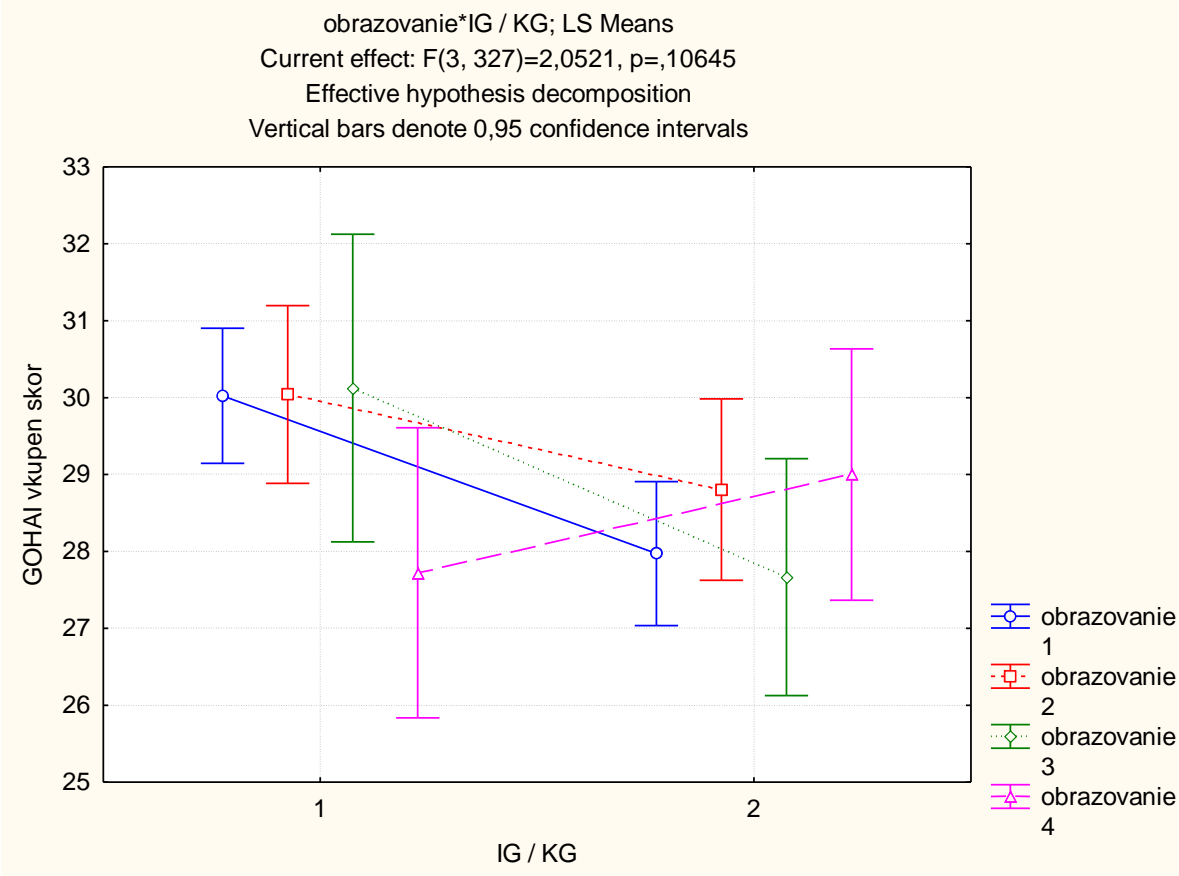

Graph 3 - ANOVA-MANOVA (total GOHAI scorellevel of education)

The main results of the analysis for evaluation of the influence of the place of living to the quality of life showed that the two factors (place of living and group affiliation to the IG and the CG) had significant influence to the total GOHAI score ( $\mathrm{p}=0.006, \mathrm{p}=0.0018)$. (Table 6)
The average values of the total GOHAI score of the patients of the IG and the CG living in urban and rural areas showed that the patients of the IG living in urban areas had the highest GOHAI score, while the lowest total score was in the patients of the CG living in rural areas. (Table 7, Graph 4)

Table 6

ANOVA-MANOVA (total GOHAI score/place of living)

\begin{tabular}{|l|r|r|r|r|l|}
\hline \multicolumn{6}{|c|}{ Univariate Tests of Significance for GOHAI total score } \\
\hline & \multicolumn{1}{|c|}{ SS } & $\begin{array}{c}\text { Degr. } \\
\text { of }\end{array}$ & \multicolumn{1}{c|}{ MS } & \multicolumn{1}{c|}{ F } & p \\
\hline Intercept & 281000.3 & 1 & 281000.3 & 17231.29 & 0.00 \\
\hline Place of living & 123.5 & 1 & 123.5 & 7.58 & 0.006 \\
\hline IG/CG & 161.8 & 1 & 161.8 & 9.92 & 0.002 \\
\hline Place of living * IG/CG & 16.2 & 1 & 16.2 & 0.99 & 0.32 \\
\hline Error & 5397.8 & 331 & 16.3 & & \\
\hline
\end{tabular}

Table 7

ANOVA-MANOVA (total GOHAI score/place of living)

\begin{tabular}{|l|c|r|r|r|r|r|}
\hline \multirow{2}{*}{$\begin{array}{c}\text { Place of } \\
\text { living }\end{array}$} & \multirow{2}{*}{ IG/CG } & \multicolumn{6}{|c|}{ Total GOHAI score } \\
\cline { 3 - 8 } & $\begin{array}{c}\text { GOHAI } \\
\text { mean }\end{array}$ & $\begin{array}{c}\text { GOHAI } \\
\text { Std. } \\
\text { Error }\end{array}$ & $\begin{array}{c}\text { GOHAI } \\
\mathbf{- 9 5 , 0 0 \%}\end{array}$ & $\begin{array}{c}\text { GOHAI } \\
\mathbf{+ 9 5 , 0 0 \%}\end{array}$ & $\mathbf{N}$ \\
\hline \multirow{2}{*}{ Urban } & IG & 30.15 & 0.43 & 29.30 & 30.99 & 89 \\
\cline { 2 - 8 } & CG & 29.19 & 0.46 & 28.29 & 30.09 & 78 \\
\hline \multirow{2}{*}{ Rural } & IG & 29.37 & 0.46 & 28.46 & 30.28 & 76 \\
\cline { 2 - 8 } & CG & 27.53 & 0.42 & 26.70 & 28.36 & 92 \\
\hline
\end{tabular}




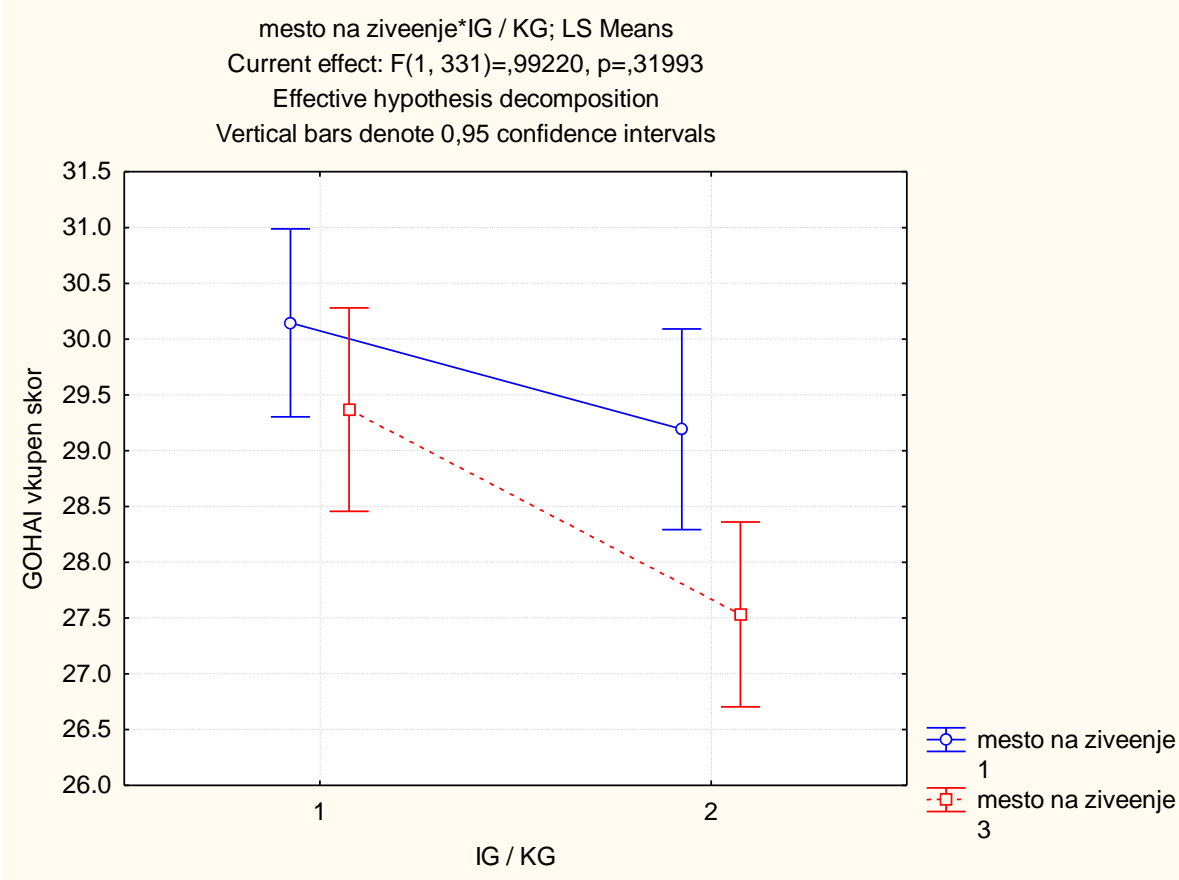

Graph 4 - ANOVA-MANOVA (total GOHAI score/place of living)

\section{Discussion}

Recently, due to the fast tempo of living, bad and low quality food, accompanied with a high dose of uncontrolled stress, the diseases of the masticatory organs have become more and more present. This is also connected with the partial or total teeth loss, which leads to the necessity of prosthetic solution for the edentulous areas.

The GOHAI indicator is a system for evaluation of the quality of oral health and its influence to the quality of life, which is the second most frequently used internationally, while it has not been used in Macedonia so far. This was one big challenge for this study.

Institutionally sheltered patients signifycantly more often had upper and lower total denture, compared to the upper partial and lower total denture, upper or lower partial denture only and upper or lower total denture only.

In the study in India in 2010 the most negative answers to the GOHAI indicator were given by the patients with prosthetic treatment from Group 1, followed by the patients from Group 2.

The Brazilian professor Bonan, in 2008, in his study did not find statistically significant differences between the quality of life at elderly people and the prosthetic treatment (total or partial denture). [9]
In both groups, the majority were Macedonians with $66.1 \%$ in the IC and $62.9 \%$ in the $\mathrm{CG}$, followed by the Albanians in the IC with $14.5 \%$ and in the CG with $12.9 \%$.

There was no significant difference in connection with the ethnic affiliation in both groups. Most of the patients in both groups were with primary education $(50.3 \%$ and $42.9 \%$ )

There was no significant difference in the level of education among the patients in both groups.

$53.9 \%$ or 89 patients from the IC and $45.9 \%$ or 78 patients were living in urban areas. There was no significant difference in the number of patients living in urban and rural areas.

There was a significant difference in the total GOHAI score among the patients of different ethnic groups. The highest score was recorded in Roma and the other nationalities, and the lowest score in the Albanians.

The difference in the total score was significant, but the level of education had no significant influence on the total GOHAI score.

The place of living in this study showed significant influence to the total score, where the patients in the IC living in cities had the highest, and the patients from the CG living in rural areas had the lowest total GOHAI score. 


\section{Conclusion}

According to the analysis of the total GOHAI score it can be concluded that the oral health is on an unsatisfactory level. This is shown by the highest score of 40 , while the maximal possible GOHAI score is 48. The largest number is of patients with upper and lower total denture, and then with upper and lower partial denture.

The ethnic affiliation and the level of education had no significant influence, while the place of living had a significant influence to the total GOHAI score.

\section{REFERENCES}

1. Тулчински Т., Варавикова Е., Новото јавно здравство. Скопје: НИП „тудентски збор“, Скопје; 2003.

2. World Health Organization. Executive Board Meeting January 2007. Report on global oral health EB120/10 and draft resolution EB120.R5. Geneva: WHO; 2007.

3. Petersen PE. Priorities for research for oral health in the $21^{\text {st }}$ century - the approach of the WHO Global Oral Health Programme. Community Dent Health 2005; 22: 71-4.

4. Petersen PE. Global research challenges for oral health. Global Forum Update Res Health 2005; 2: 181-4.

5. Raphael D, Brown I, Renwick R, Rootman I. Quality of life theory and assessment; what are the implications for health promotion. Issues in Health Promotion Series. University of Toronto, Centre for Health Promotion, 2004.

6. Michael I. MacEntee 2007; 138; 47S-52S J Am Dent Assoc. Quality of life as an Indicator of Oral Health in Older People.

7. Cohen L, Jago J. Toward the formation of sociodental indicators. Int J Health Serv 1976; 6(4): 681-98.

8. Шапуриќ М. Јавно-здравствени аспекти на оралното здравје кај возрасната популација над 65 години во Република Македонија-состојба и импликаци за стратешко планирање. [Магистерски труд]. Скопје: Медицински факултет; 2010.

9. Bonan PR, Borges SP, Haikal DS. Unsatisfactory oral and rehabilitation conditions dissociated from quality of life perception in institutionalized and community-dwelling elderly. Journal of Dental Science. 2008; 2: 115-119.
Резиме

\section{ВЛИЈАНИЕ НА ЕТНИЧКАТА ПРИПАДНОСТ, НИВОТО НА ОБРАЗОВАНИЕ И МЕСТОТО НА ЖИВЕЕЊЕ ВРЗ ОРАЛНОТО ЗДРАВЈЕ КАЈ ГЕРИЈТРИСКА ПОПУЛАЦИЈА СО ТОТАЛНИ И ПАРЦИЈАЛНИ ПРОТЕЗИ ВО РЕПУБЛИКА МАКЕДОНИЈА}

\section{Наташа Ставрева, Љубен Гугувчевски, Билјана Капушевска}

Оддел за протетика, Стоматолошки факултет, Универзитет „Св. Кирил и Методиј“, Скопје, Р. Македонија

Boвeg: Здравјето е главна компонента на квалитетот на животот, додека оралното здравје е составна компонента на севкупното здравје. Социодемографските карактеристики се едни од битните фактори за перцепција на оралното здравје и квалитетот на животот. Главна цел на оваа студија беше да се изврши процена на квалитетот на животот кај геријатриска популација (лица постари од 65 години) со вградени орално-протетски помагала во зависност од етничката припадност, нивото на образование и местото на живеење, како социодемографски карактеристики.

Мат̄еријали и мет̄оgи: Истражувањето претставуваше проспективна трансферзална (cross-sectional) студија, спроведена кај 165 пациенти во Геронтолошки завод (испитувана група - ИГ) и 170 пациенти од стоматолошките специјалистички ординации (контролна група КГ), на возраст над 65 години. За статистичката обработка на податоците беше користена статистичката програма SPSS за Windows ver. 13.0.

Резулйайи и gискусија: Доминираа пациенти со вградени горна и долна тотална протеза (43,6\% vs. $26,5 \%)$. Највисока вредност за GOHAI скор имаа испитаниците од ИГ од категоријата останати националности $(32,08)$ и Ромите од ИГ $(31,00)$, додека најмала вредност на овој скор беше регистрирана кај Албанците припадници на КГ $(25,91)$. Најголема вредност на вкупниот GOHAI скор од 30,15 се сретна кај испитаниците од ИГ од урбаните подрачја.

Заклучок. Квалитетот на животот и оралното здравје кај геријатриските пациенти се на незадоволително ниво, со сигнификантно влијание на местото на живеење и несигнификантно влијание на етничката припадност и нивото на образование врз вкупниот GOHAI скор.

Клучни зборови: GOHAI индикатор, квалитет на живот, пол, возраст 


\section{Annex 1}

ФОРМУЛАР НА СЗО ЗА ПРОЦЕНКА НА ОРАЛНОТО ЗДРАВЈЕ (1986)

(Модифичиран со Проїрамайа за орално здравје на СЗО, Женева 2003)

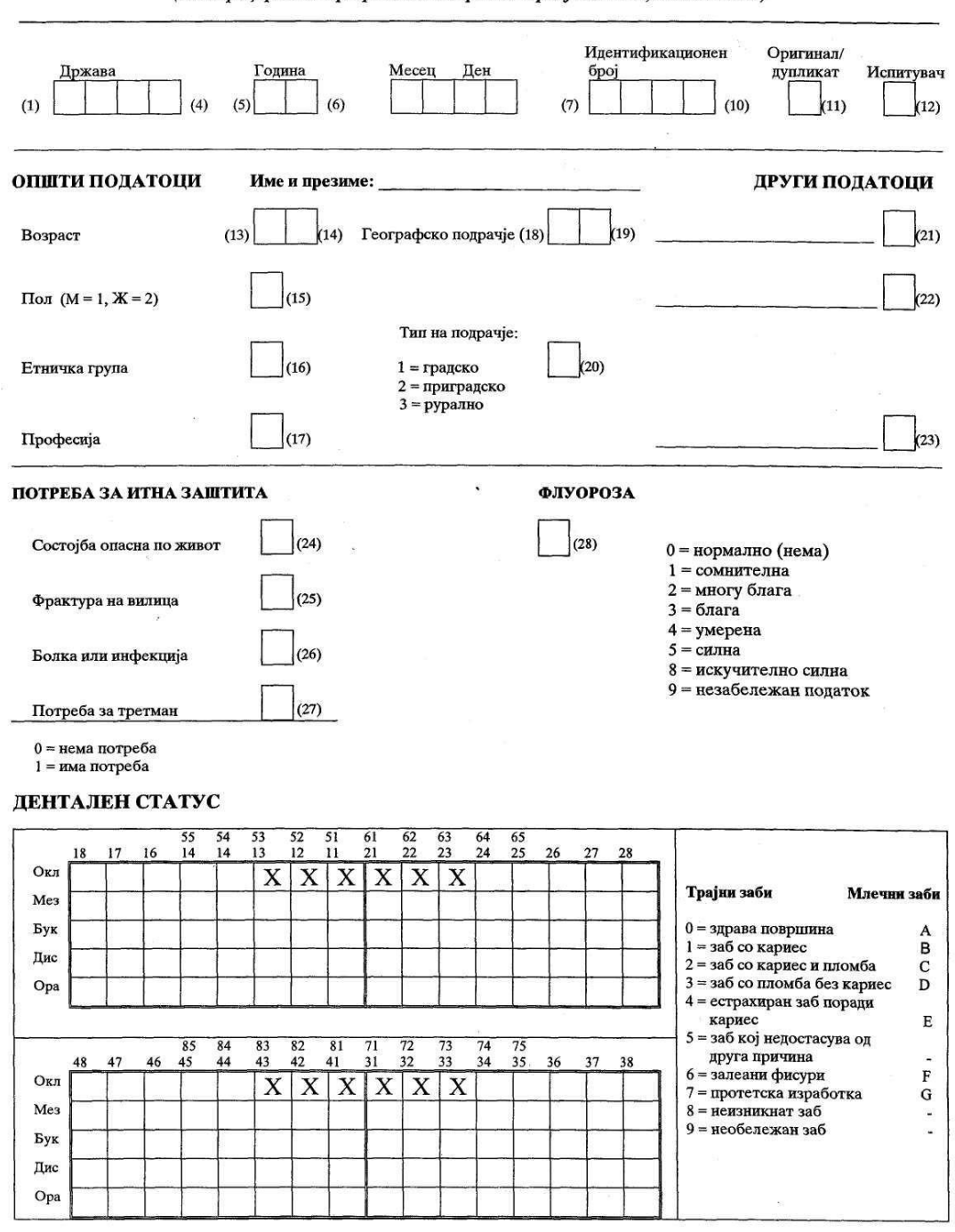

$\mathrm{ec} / \mathrm{rH}$

Annex 2

GOHAI indicator - Indicator for evaluation of oral health at geriatric population

General (Geriatric) Oral Health Assessment Index / GOHAI

1. How often did you limit the kinds or amounts of food you eat because of problems with your teeth or dentures?

2. How often did you have trouble biting or chewing different kinds of food, such as firm meat or apples?

3. How often were you able to swallow comfortably?

4. How often have your teeth or dentures prevented you from speaking the way you wanted?

5. How often were you able to eat anything without feeling discomfort?

6. How often did you limit contacts with people because of the condition of your teeth or dentures?

7. How often were you pleased or happy with the looks or your teeth and gums, or dentures?

8. How often did you use medication to relieve pain or discomfort from around your mouth?

9. How often were you worried or concerned about the problems with your teeth, gums or dentures?

10. How often did you feel nervous or self-conscious because of problems with your teeth, gums or dentures?

11. How often did you feel uncomfortable eating in front of people because of problems with your teeth or dentures?

12. How often were your teeth or gums sensitive to hot, cold or sweets? 